\title{
Macrophage Infiltration Predicts a Poor Prognosis for Human Ewing Sarcoma
}

\author{
Toshifumi Fujiwara, ${ }^{*}$ Jun-ichi Fukushi, ${ }^{*}$ \\ Shunsaku Yamamoto, * Yoshihiro Matsumoto, * \\ Nokitaka Setsu, ${ }^{\dagger}$ Yoshinao Oda, ${ }^{\dagger}$ \\ Hisakata Yamada, ${ }^{\ddagger}$ Seiji Okada, ${ }^{\S}$ Kosuke Watari," \\ Mayumi Ono," Michihiko Kuwano," \\ Satoshi Kamura, ${ }^{*}$ Keiichiro lida, ${ }^{*}$ Yuko Okada, ${ }^{*}$ \\ Mihoko Koga, ${ }^{*}$ and Yukihide Iwamoto*

\begin{abstract}
From the Departments of Orthopaedic Surgery,* Anatomic Pathology, and Advanced Medical Initiatives, ${ }^{\circledR}$ and the Division of Host Defense, ${ }^{\ddagger}$ Graduate School of Medical Sciences, and the Department of Pharmaceutical Oncology " and the Laboratory of Molecular Cancer Biology, Department of Pharmaceutics," Graduate School of Pharmaceutical Sciences, Kyushu University, Fukuoka, Japan
\end{abstract}

Ewing sarcoma-primitive neuroectodermal tumor (EWS) is associated with the most unfavorable prognosis of all primary musculoskeletal tumors. The objective of the present study was to investigate whether tumor-associated macrophages (TAMs) affect the development of EWS. TAMs were isolated from mouse xenografts using $\mathrm{CD11b}$ magnetic beads and examined for their cytokine expression and osteoclastic differentiation. To evaluate the role of TAMs in xenograft formation, liposome-encapsulated clodronate was used to deplete TAMs in mice. Macrophage infiltration and tumor microvascular density were histologically evaluated in 41 patients with EWS, and association with prognosis was examined using Kaplan-Meier survival analysis. In mouse EWS xenografts, TAMs expressed higher concentrations of cytokines including interleukin-6, keratinocyte-derived chemokine, and monocyte chemotactic protein-1. TAMs were more capable than normal monocytes of differentiating into tartrate-resistant acid phosphatase-positive giant cells. Depleting macrophages using liposome-encapsulated clodronate significantly inhibited development of EWS xenografts. In human EWS samples, higher levels of CD68-positive macrophages were associated with poorer overall survival. In addition, enhanced vascularity, increase in the amount of C-reactive protein, and higher white blood cell counts were also associated with poor prognosis and macrophage infiltra- tion. TAMs seem to enhance the progression of EWS by stimulating both angiogenesis and osteoclastogenesis. Further investigation of the behavior of TAMs may lead to development of biologically targeted therapies for EWS. (Am J Pathol 2011, 179:1157-1170; DOI: 10.1016/j.ajpath.2011.05.034)

Ewing sarcoma-primitive neuroectodermal tumor (EWS) is a small round-cell tumor type that typically develops in the bones of children and young adults. EWS is aggressive, with a tendency to metastasize to lung and bone. As a result, these tumors are associated with the most unfavorable prognosis of all primary musculoskeletal tumors. Development of multimodal therapeutic regimens that include chemotherapy, irradiation, and surgery has increased the long-term survival rate in patients with localized disease. Smaller improvements, however, have been observed in patients with metastatic or recurrent disease. ${ }^{1}$

The initial symptoms of EWS include pain, swelling, and fever, and laboratory findings including increased concentrations of white blood cell counts, higher C-reactive protein (CRP) concentration, and sedimentation rate are frequently observed. These findings indicate the existence of inflammation and sometimes lead to a misdiagnosis of osteomyelitis and delay in treatment. ${ }^{2,3}$ Biological mechanisms that account for the inflammation involved in EWS remain uncertain. A better understanding of the characteristics of EWS may thus lead to future successful development of biologically targeted therapies.

Recent studies have highlighted the importance of cells from the tumor stroma. Blood vessels, fibroblasts, and inflammatory cells such as lymphocytes, neutrophils,

Supported by a Grant-in-Aid for Scientific Research (No. 19390397) from the Japan Society for the Promotion of Science and a Grant-in-Aid for Clinical Research Evidence-Based Medicine and Cancer Research from the Ministry of Health, Labour and Welfare of Japan (both to Y.I.).

Accepted for publication May 26, 2011.

Supplemental material for this article can be found at http://ajp. amjpathol.org or at doi: 10.1016/j.ajpath.2011.05.034

Address reprint requests to Jun-ichi Fukushi, M.D., Ph.D., Department of Orthopaedic Surgery, Graduate School of Medical Sciences, Kyushu University, Maidashi 3-1-1, Fukuoka 812-8582, Japan. E-mail: fukushi@med.kyushu-u.ac.jp. 
and macrophages are frequently observed in the tumor stroma. Interactions between stromal cells and tumor cells are thought to be essential for tumor malignancy. ${ }^{4}$ For example, angiogenesis is clearly important for tumor growth and metastasis, and antibodies that target vascular endothelial growth factor (VEGF) are currently used to treat solid tumors. ${ }^{5}$ In addition, fibroblasts and neutrophils that infiltrate the tumor stroma are important for tumor initiation, growth, and metastasis. ${ }^{6-8}$ Recently, tumor-infiltrating T cells have been reported to be associated with a favorable prognosis in EWS. ${ }^{9}$

Among stromal cells, tumor-associated macrophages (TAMs) have an important role in solid-tumor behavior including invasion, angiogenesis, and metastasis. ${ }^{10}$ Macrophages have a wide phenotypic diversity and can be classified into two activation phenotypes, M1 and M2. ${ }^{11,12}$ Classically, activated M1 macrophages are inflammatory and can exert cytotoxic activity; in contrast, activated M2 macrophages are anti-inflammatory and promote wound healing, angiogenesis, and tissue remodeling. TAMs often exhibit features of M2 macrophages and produce a number of cytokines and growth factors that promote tumor progression. TAMs also release a number of proteolytic enzymes that act to break down the extracellular matrix and basement membrane, enabling tumor cells to invade other tissues and endothelial cells to form vascular structures. ${ }^{13}$ TAM accumulation is generally associated with poor prognosis in patients with breast, prostate, bladder, and cervical cancers. ${ }^{14-18}$ In patients with gastrointestinal stromal tumors, macrophages are more abundantly infiltrated in metastatic lesions than in primary tumors. ${ }^{19}$ In glioblastoma and melanoma, there is a significant correlation between the number of infiltrating macrophages and microvascular density or tumor progression. ${ }^{20,21}$ However, in osteosarcoma, activating macrophages with the muramyl tripeptide have been used as cytotoxic therapy, resulting in improvement in overall survival, which indicates that the TAMs in osteosarcoma have a suppressive effect on tumor progression. ${ }^{22,23}$

Currently, little is known about the role of TAMs in EWS. Lau et $\mathrm{al}^{24}$ reported that TAMs isolated from EWS arising in bone were capable of differentiating into osteoclasts, major mediators of tumor osteolysis. Additional studies are required to assess the function of TAMs in EWS. In the present study, TAMs were isolated from mouse EWS xenografts, and the characteristics of these cells were investigated. We also sought to determine the prognostic significance of TAMs in patients with EWS.

\section{Materials and Methods}

\section{Clinical Samples}

The study population consisted of 76 serial cases retrieved from the archives of the Department of Anatomical Pathology, Pathological Sciences, Graduate School of Medical Science, Kyushu University, Fukuoka, Japan. The tissues were collected during primary tumor biopsy at diagnosis between 1978 and 2009. In each case, a diagnosis of EWS was made on the basis of histologic features. Of these 76 cases, 35 were excluded, 27 be- cause of lack of availability of adequate tissue and 8 because of lack of follow-up data; thus, 41 patients were included in the present study. All 41 patients had primary EWS, and 40 underwent treatment with systemic multipleagent chemotherapy in combination with surgery and/or radiation. One patient refused systemic chemotherapy after wide surgical resection, however, she has been disease-free for 8 years after the surgery. Clinical data were obtained by reviewing patient records, and survival data were collected during the summer of 2010. The Institutional Review Board at Kyushu University approved the use of human specimens for this study.

\section{Immunohistochemistry}

Antibodies specific for human CD68, CD31, and MIB1 were obtained from Dako A/S (Glostrup, Denmark) and were used to evaluate human EWS clinical samples. To visualize macrophages and endothelial cells in mouse xenografts, anti-F4/80 (AbD Serotec, Ltd., Kidlington, Oxfordshire, England), anti-CD99 (Dako A/S), and anti-CD31 (BMA Biomedicals AG, Basel, Switzerland) antibodies were used. Wholesection samples were fixed in $10 \%$ neutral buffered formalin and embedded in paraffin. After the sections were deparaffinized in xylene and rehydrated in a graded ethanol series, they were subjected to microwave pretreatment with citrate buffer ( $\mathrm{pH}$ 6.0). After incubation with each antigenspecific antibody, samples were incubated with horseradish peroxidase-labeled goat anti-mouse antibodies (Dako $A / S$ ). The reaction was visualized using the diaminobenzidine substrate system (Wako Pure Chemical Industries, Ltd., Osaka, Japan), and the samples were counterstained with diluted hematoxylin. To count the macrophages, an image with an area of $0.64 \mathrm{~mm}^{2}$ was created from six different visual fields. The number of CD68- or F4/80-positive cells in six random field profiles was used for subsequent statistical analysis. To evaluate microvascular density, CD31-positive vessels were counted in six random field profiles. Images were acquired using an AX70 microscope equipped with a DP72 camera (both from Olympus Corp., Tokyo, Japan).

An antibody specific for human CD14 was obtained from Abcam, Inc. (Cambridge, MA) and was used to evaluate the co-expression of CD14 and CD68 in 10 different EWS clinical samples. Tissue samples were deparaffinized, rehydrated via an ethanol series, and treated with citrate buffer ( $\mathrm{pH}$ 6.0). After blocking, double fluorescent immunostaining reactions were performed using anti-CD14 (mouse lgG2a) and anti-CD68 (mouse IgG1) antibodies. The reactions were visualized using secondary fluorescently labeled antibodies including goat anti-mouse IgG2a-Alexa Fluor 546 and goat antimouse IgG1-Alexa Fluor 488 (both from Invitrogen Corp., Carlsbad, CA), mounted in Vectashield mounting medium containing DAPI (Vector Laboratories, Inc., Burlingame, CA), and imaged using fluorescence microscopy (Olympus Corp.). The stained cells were counted in four different fields of vision with an area of $0.064 \mathrm{~mm}^{2}$, and a total area of $0.256 \mathrm{~mm}^{2}$ was investigated for each case. 


\section{Cell Lines}

RD-ES, SK-N-MC, and SK-ES-1 EWS cell lines were obtained from the American Type Culture Collection (Manassas, VA). WE-68 and VH-64 cells were kindly provided by Dr. Frans van Valen (Westfälische Wilhelms-University, Münster, Germany). These cells have been characterized previously. ${ }^{25}$ TC-71 cells were obtained from the Coriell Institute (Camden, NJ). The murine macrophage RAW264.7 cell line was obtained from the European Collection of Cell Cultures (Salisbury, Wiltshire, England). RD-ES, SK-ES-1, WE-68, and VH-64 cells were cultured in RPMI 1640 (Invitrogen Corp.) supplemented with $10 \%$ fetal bovine serum (HyClone Laboratories, Inc., Logan, UT) at $37^{\circ} \mathrm{C}$ in an atmosphere of $5 \% \mathrm{CO}_{2}$. SK-N-MC, TC-71, and RAW264.7 cells were cultured in Dulbecco's modified Eagle's medium (DMEM) (Invitrogen Corp.) supplemented with 10\% fetal bovine serum at $37^{\circ} \mathrm{C}$ in an atmosphere of $5 \% \mathrm{CO}_{2}$.

\section{Mouse Xenografts}

Female 6-week-old BALB/c nude mice were obtained from Charles River Japan (Fukuoka, Japan) and maintained in a specific pathogen-free environment throughout the experiment. Cells $\left(5.0 \times 10^{6}\right)$ derived from two EWS cell lines, RD-ES and TC-71, were resuspended in DMEM and Matrigel (BD Biosciences, Franklin Lakes, NJ) at a ratio of 1:1, and were injected into two subcutaneous locations on the back of each mouse. Tumor xenografts were excised at 4 weeks after inoculation, and were used for further experiments. Experiments involving animals were performed in compliance with the guidelines established by the Animal Care and Use Committee of Kyushu University.

\section{Isolation of $\mathrm{CD} 11 b^{+}$Cells}

$\mathrm{CD}_{11 \mathrm{~b}^{+}}$cells were isolated from mouse EWS xenograft tumors via magnetic sorting using CD11b MicroBeads (Miltenyi Biotec $\mathrm{GmbH}$, Bergisch-Gladbach, Germany). In brief, tissues were minced in $10 \mathrm{~mL}$ DMEM, and collagenase L (Nitta Gelatin, Osaka, Japan) and DNase I (F. Hoffman-La Roche AG, Basel, Switzerland) were added. The mixture was incubated for 30 minutes at $37^{\circ} \mathrm{C}$ under gentle agitation. Digestion was stopped using fetal bovine serum, and the cell suspension was washed and passed through a 70- $\mu \mathrm{m}$ mesh nylon screen. The cells were incubated with CD11b MicroBeads for 15 minutes at $4^{\circ} \mathrm{C}$ and loaded onto a MIDIMACS column (Miltenyi Biotec $\mathrm{GmbH}$ ) according to the manufacturer's instructions. Isolated CD $11 b^{+}$cells from xenografts were used as TAMs for further experiments. CD11 ${ }^{+}$cells were also isolated from mouse spleen and liver tissues, and were used as control macrophages. For cell surface staining, single-cell suspensions were incubated with fluorescein isothiocyanate-conjugated anti-CD11b monoclonal antibody (Miltenyi Biotec $\mathrm{GmbH}$ ), allophycocyanin-conjugated anti-CD11b and anti-CD45 monoclonal antibodies, and phycoerythrin-conjugated anti-F4/80 monoclonal antibody (eBioscience, Inc., San Diego, CA) for 15 minutes at $4^{\circ} \mathrm{C}$. The stained cells were run on a FACSCalibur flow cytometer (BD Biosciences). Data were analyzed using the CellQuest software program (BD Biosciences).

\section{Cytokine Expression Analysis}

Expression of multiple cytokines was analyzed in $\mathrm{CD}_{11 \mathrm{~b}^{+}}$cells and EWS cell lines using Luminex 100 (Luminex Corp., Austin, TX) according to the manufacturer's instructions. To collect conditioned medium, EWS cells $\left(1 \times 10^{6} /\right.$ well $)$ and CD $11 b^{+}$cells $\left(5 \times 10^{5} /\right.$ well $)$ were incubated in serum-free DMEM for 24 hours and 72 hours, respectively. The Human MultiAnalyte Profiling Base Kit A (R\&D Systems, Inc., Minneapolis, MN) was used to examine EWS cells for expression of interleukin (IL) $-1 \alpha, \mathrm{IL}-1 \beta, \mathrm{IL}-1$ receptor antagonist, IL-2, IL-6, IL-8, IL-10, IL-17, basic fibroblast growth factor, tumor necrosis factor- $\alpha$, interferon- $\gamma$, granulocyte-macrophage colony-stimulating factor (M-CSF), macrophage inflammatory protein (MIP)-1 $\alpha$, MIP-1 $\beta$, monocyte chemotactic protein-1 (MCP-1), regulated on activation normal T cell expressed and secreted (RANTES), and VEGF. A multiplex mouse cytokine/chemokine kit (Millipore Corp., Billerica, MA) was used to detect mouse IL-1 $\alpha$, IL-1 $\beta, \mathrm{IL}-6, \mathrm{IL}-10$, IL-17, keratinocyte-derived chemokine, MCP-1, MIP-1 $\alpha$, MIP- $1 \beta$, RANTES, and VEGF.

To examine the effects of macrophages on VEGF production by EWS cells, $5 \times 10^{4}$ TAMs isolated from EWS xenografts were incubated in $500 \mu \mathrm{L}$ serum-free DMEM for 72 hours. The serum-free DMEM or conditioned medium collected from TAMs was transferred to a monolayer of $1 \times 10^{5}$ RD-ES or TC-71 EWS cells and collected after an additional 48 hours of incubation. The VEGF concentration in the conditioned medium was measured using a human VEGF enzyme-linked immunosorbent assay kit (R\&D Systems, Inc.).

\section{In Vitro Migration Assay}

A migration assay was performed using Transwell chambers (Corning Costar Corp., Cambridge, MA) with 6.5-mmdiameter polycarbonate filters (8- $\mu \mathrm{m}$ pore size) as described previously. ${ }^{25}$ In brief, polyvinylpyrrolidone-free polycarbonate filters in the upper chamber were coated with type 1 collagen (Nitta Gelatin, Inc.) and inserted into the lower chambers. RAW264.7 cells $\left(2.0 \times 10^{5}\right.$ /well) were suspended in $200 \mu \mathrm{L}$ serum-free DMEM and seeded in the upper chamber. The lower chamber was filled with serumfree DMEM as a control sample or conditioned medium obtained from CD $11 \mathrm{~b}^{+}$cells. In some experiments, EWS cells were plated in the lower chamber $\left(2.0 \times 10^{5} /\right.$ well), and VEGF receptor tyrosine kinase inhibitor IV (VEGFRTKI) (Merck KGaA, Darmstadt, Germany) was added to both chambers at various concentrations $(0,0.1,1$, or 10 $\mathrm{nmol} / \mathrm{L})$ to examine the involvement of VFGF signaling in cell migration. RAW264.7 cells were allowed to migrate for 4 hours at $37^{\circ} \mathrm{C}$, and the cells that migrated to the lower side of the filter were stained and counted as described previously. ${ }^{24}$ Each experiment was repeated at least three times. 
1160 Fujiwara et al

AJP September 2011, Vol. 179, No. 3

Table 1. Human and Mouse Primer Sequences Used for Conventional RT-PCR

\begin{tabular}{|c|c|c|}
\hline Gene & Primer sequence & Amplicon size (bp) \\
\hline \multicolumn{3}{|l|}{$G A P D H(H)$} \\
\hline Forward & $5^{\prime}-\mathrm{ACCACAGTCCATGCCATCAC-3^{ \prime }}$ & 452 \\
\hline Reverse & 5'-TCCACCACCCTGTTGCTGTA-3' & \\
\hline \multicolumn{3}{|l|}{ GAPDH (M) } \\
\hline Forward & $5^{\prime}$-GTGGCAAAGTGGAGATGGTTGCC-3' & 290 \\
\hline Reverse & 5'-GATGATGACCCGTTTGGCTCC-3' & \\
\hline \multicolumn{3}{|l|}{$M-C S F(H)$} \\
\hline Forward & $5^{\prime}$-CAGTTGTCAAGGACAGCAC-3' & 671 \\
\hline Reverse & $5^{\prime}$-GCTGGAGGATCCCTCGGACTG-3' & \\
\hline \multicolumn{3}{|l|}{ RANKL $(\mathrm{H})$} \\
\hline Forward & 5'-GCCAGTGGGAGATGTTAG-3' & 487 \\
\hline Reverse & 5'-TTAGCTGCAAGTTTTCCC-3' & \\
\hline \multicolumn{3}{|c|}{ EWS/FL/1 (H) } \\
\hline Forward & $5^{\prime}$-CCACTAGTTACCCACCCCAAACTG-3' & 332 (type 1) \\
\hline Reverse & 5'-GTGATACAGCTGGCGTTGGCG-3' & 398 (type 2) \\
\hline
\end{tabular}

$\mathrm{H}$, human; $\mathrm{M}$, mouse.

\section{Osteoclastic Differentiation Assay}

CD11 $\mathrm{b}^{+}$cells were isolated and plated in 96-well plates at $5 \times 10^{4}$ cells/well in $200 \mu \mathrm{L}$ DMEM ( $\left.\mathrm{pH} 7.4\right)$ containing $10 \%$ fetal bovine serum, $50 \mathrm{ng} / \mathrm{mL}$ recombinant mouse M-CSF (R\&D Systems, Inc.), and $50 \mathrm{ng} / \mathrm{mL}$ recombinant mouse receptor activator of $N F-\kappa B$ ligand (RANKL) (R\&D Systems, Inc.). At the end of the 4-day culture period, cells were fixed, and their tartrate-resistant acid phosphatase (TRAP) activity was visualized using a TRAP staining kit (Primary Cell Co., Ltd., Sapporo, Japan). TRAP-positive multinucleated giant cells containing three or more nuclei were counted under a microscope in four random field profiles. Each experiment was repeated at least three times.

\section{RNA Isolation and RT-PCR}

Total RNA was extracted from each cell pellet using an RNeasy Mini Kit (Qiagen GmbH, Hilden, Germany). First- strand complementary DNA was generated from total RNA using a First Strand cDNA Synthesis Kit (Invitrogen Corp.) with random hexamer primers. Samples were then subjected to PCR amplification with oligonucleotide primers to detect the expression of RANKL and M-CSF mRNA (Table 1). The PCR products were electrophoresed through a $1.5 \%$ agarose gel (Invitrogen Corp.) containing ethidium bromide (Biotium, Inc., Hayward, CA). Real-time quantitative RT-PCR was performed to compare the level of expression of each mRNA in CD11 ${ }^{+}$cells using the LightCycler system (Hoffman-La Roche AG) with the SYBR Green I reagent (Takara Bio, Inc., Tokyo, Japan). Expression levels of cathepsin $\mathrm{K}$; triggering receptor expressed on myeloid cells-2 (TREM2); osteopontin; TRAP, nuclear factor of activated $\mathrm{T}$ cells, cytoplasmic 1; and osteoactivin were examined using specific primers (Table 2). mRNA expression levels were analyzed using the LightCycler version 3.5 software program (Hoffman-La Roche AG). Data were normalized using glyceraldehyde3-phosphate dehydrogenase as a reference gene.

Table 2. Mouse Primer Sequences Used for Real-Time RT-PCR

\begin{tabular}{|c|c|c|}
\hline Gene & Primer sequence & Amplicon size (bp) \\
\hline \multicolumn{3}{|l|}{ GAPDH } \\
\hline Forward & $5^{\prime}$-GGAAGGCCATGCCAGTGAGC-3' & \multirow[t]{2}{*}{194} \\
\hline Reverse & $5^{\prime}$-CATTGTGGAAGGGCTCATGA-3' & \\
\hline \multicolumn{3}{|l|}{ Cathepsin $\mathrm{K}$} \\
\hline Forward & $5^{\prime}-$ TGTATAACGCCACGGCAAA-3' & \multirow[t]{2}{*}{195} \\
\hline Reverse & 5'-GGTTCACATTATCACGGTCACA-3' & \\
\hline \multicolumn{3}{|l|}{ TREM2 } \\
\hline Forward & $5^{\prime}$ - CTGCACTTCAAGGGAAAAGC-3' & \multirow[t]{2}{*}{203} \\
\hline Reverse & $5^{\prime}$ - CAGTGCTTCAAGGCGTCATA-3' & \\
\hline \multicolumn{3}{|l|}{ Osteopontin } \\
\hline Forward & 5'-GGCATTGCCTCCTCCCTC-3' & \multirow[t]{2}{*}{69} \\
\hline Reverse & 5'-GCAGGCTGTAAAGCTTCTCC-3' & \\
\hline \multicolumn{3}{|c|}{ 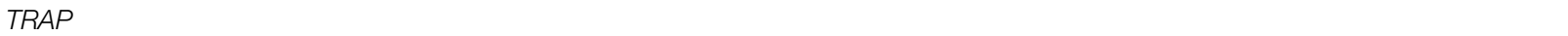 } \\
\hline Forward & $5^{\prime}-{ }^{\prime}$ ACCTGTGTGGACATGACC $-3^{\prime}$ & \multirow[t]{2}{*}{151} \\
\hline Reverse & $5^{\prime}$-CAGATCCATAGTGAAACCGC-3' & \\
\hline \multicolumn{3}{|l|}{ NFATC1 } \\
\hline Forward & $5^{\prime}$-AATAACATGCGAGCCATCATC-3' & \multirow[t]{2}{*}{109} \\
\hline Reverse & 5'-TCACCCTGGTGTTCTTCCTC-3' & \\
\hline \multicolumn{3}{|l|}{ Osteoactivin } \\
\hline Forward & 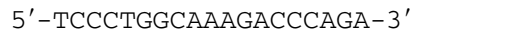 & \multirow[t]{2}{*}{107} \\
\hline Reverse & 5'-TTTGTACAGCAAGATGGTAACCATG-3' & \\
\hline
\end{tabular}


A

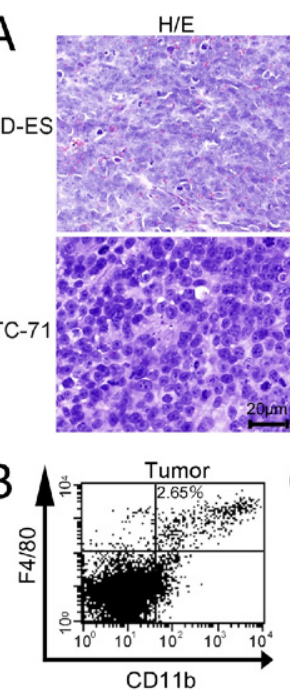

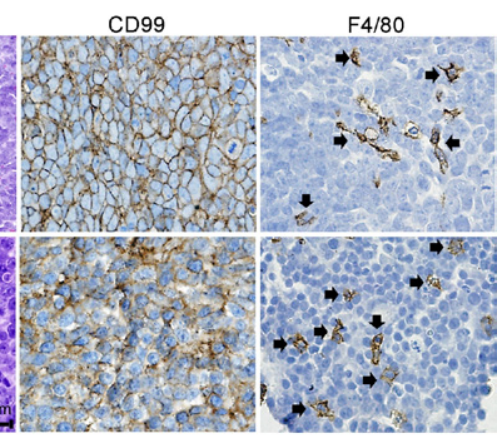
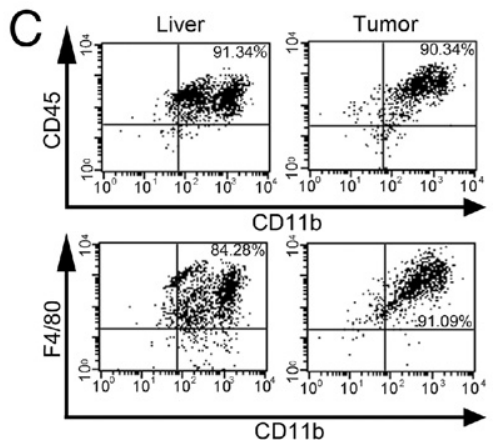

Figure 1. Identification and isolation of TAMs from mouse EWS xenograft tumors. A: Immunohistochemical staining for CD99 and F4/80 in mouse EWS xenografts. Nude mice were subcutaneously inoculated with RD-ES or TC-71 EWS cells. EWS tumors were characterized by using H\&E staining and CD99 immunostaining. Representative images of EWS xenografts infiltrated by F4/80-positive macrophages are shown (arrow). Scale bar $=20 \mu \mathrm{m}$. B: Surface marker expression on dissociated xenograft cells. After mincing, xenograft cells were dissociated using collagenase and DNase and were subjected to flow cytometric analysis. C: Surface marker expression on isolated $\mathrm{CD} 11 \mathrm{~b}^{+}$cells. After isolating cells using anti-CD11b beads, cells from EWS tumor xenografts (TAMs) or liver (control macrophages) were subjected to flow cytometric analysis.

\section{In Vivo Macrophage Depletion}

Liposome-encapsulated clodronate ( $\mathrm{Cl}_{2} \mathrm{MDP}$-Lip) was prepared as described previously. ${ }^{26-28}$ In brief, $11 \mathrm{mg}$ cholesterol (Sigma-Aldrich Corp., St. Louis, MO) and 75 mg phosphatidylcholine (Nacalai Tesque, Inc., Kyoto, Japan) were combined with $10 \mathrm{~mL} 0.7 \mathrm{mmol} / \mathrm{L} \mathrm{Cl} \mathrm{Cl}_{2} \mathrm{MDP}$ (Sigma-Aldrich Corp.) solution and sonicated gently. The resulting liposomes were washed three times to eliminate any free drug. Empty liposomes were prepared as control samples under the same conditions using PBS instead of $\mathrm{Cl}_{2} \mathrm{MDP}$. To assess the inhibitory effects of $\mathrm{Cl}_{2} \mathrm{MDP}$-Lip on RD-ES tumor proliferation, $\mathrm{Cl}_{2}$ MDP-Lip or PBS-Lip was administered 1 day before inoculation of RD-ES cells. Every 3 days, the mice received $200 \mu \mathrm{L}$ liposomes administered through a tail vein via a 28 -gauge needle. ${ }^{28}$ Five mice were included in each group, and the length and width of the tumors were measured every 3 days. Mice were sacrificed at 3 weeks after inoculation, and tumor masses were measured. All experiments were repeated three times.

\section{Statistical Analysis}

Survival curves were calculated using the Kaplan-Meier method, and the log-rank test was used for survival analysis. Fisher's exact test was used to compare catego-

rized variables. The hazard ratios for risk factors for death were evaluated using the Cox proportional hazards regression model. $P<0.05$ was considered statistically significant. Data in graphs are given as mean \pm SD. The Mann-Whitney U-test was used for two-group comparisons. All data analysis was performed using a statistical software package (SAS Institute, Inc., Cary, NC).

\section{Results}

\section{Identification and Isolation of TAMs from EWS Xenografts}

To determine whether macrophages infiltrate EWS tumors, tumor xenografts were established by subcutaneously inoculating nude mice with RD-ES or TC-71 cells. Four weeks after inoculation, xenografts were excised, and the infiltrating macrophages were examined. Xenografts were identified as EWS tumors by their characteristic CD99 staining (Figure 1A) and their specific mRNA expression of the EWS/FLI1 fusion gene (see Supplemen-

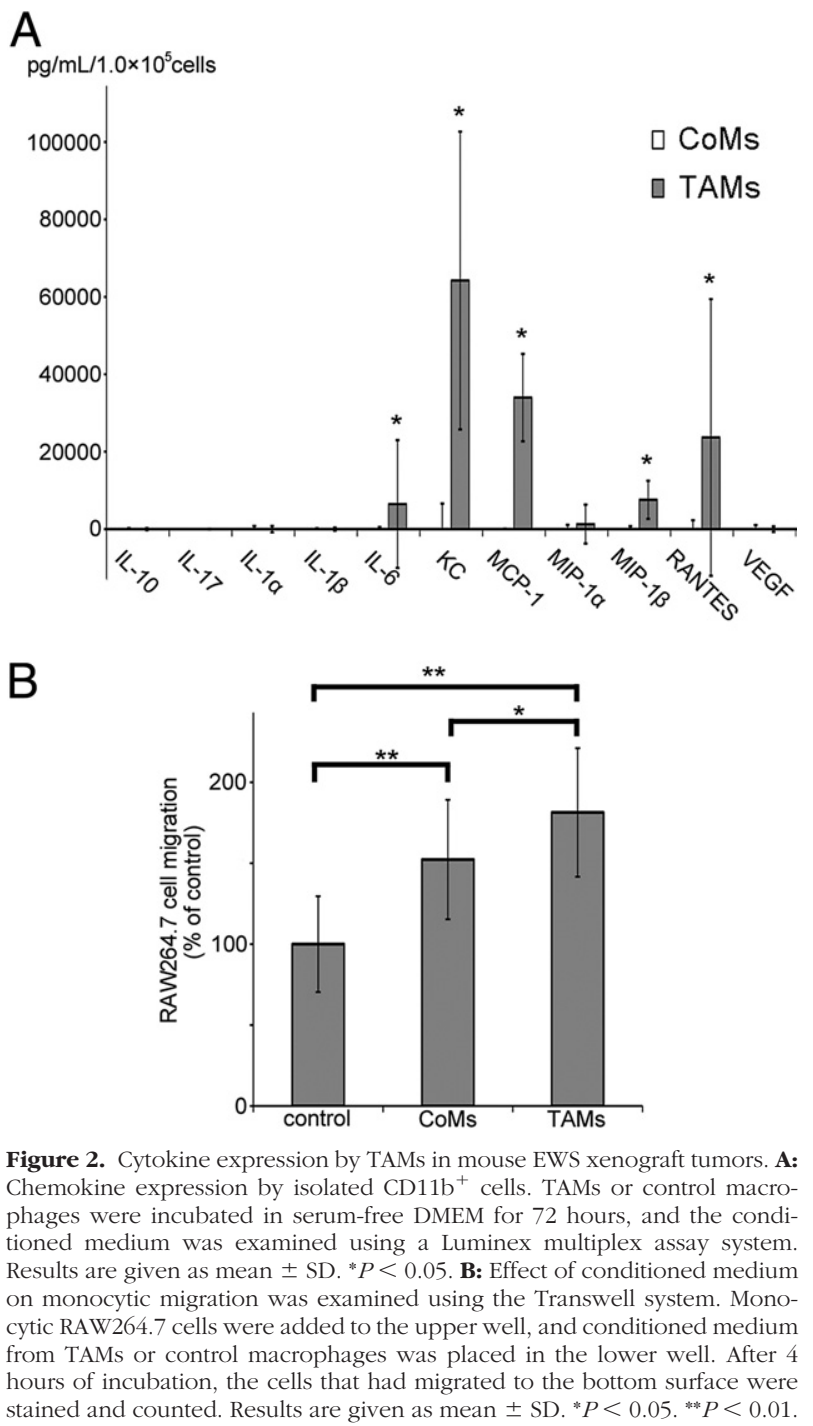


tal Figure S1 at $h$ ttp://ajp.amjpathol.org). Immunostaining revealed a number of F4/80-positive macrophages among the homogeneous small and round tumor cells in both RD-ES and TC-71 xenografts (Figure 1A). Flow cytometric analysis of collagenase-treated tumors revealed that approximately $2 \%$ of the xenograft cells were $\mathrm{CD}_{11 \mathrm{~b}^{+}}$and $\mathrm{F} 4 / 80^{+}$(Figure $1 \mathrm{~B}$ ), which suggests that these cells were TAMs.

Using antibody-conjugated magnetic beads, we isolated TAMs from EWS xenografts based on their expression of $\mathrm{CD} 11 \mathrm{~b}$. The $\mathrm{CD} 11 \mathrm{~b}^{+}$mononuclear cells were isolated as control macrophages from liver and spleen. Flow cytometric analysis demonstrated that approximately $90 \%$ of the isolated cells were positive for both $\mathrm{CD} 11 \mathrm{~b}$ and F4/80 (Figure 1C), which suggests that these cells could be used for further experiments.

\section{Cytokine and Chemokine Expression by EWS-Associated TAMs}

Expression of various cytokines and chemokines by TAMs was examined by using the Luminex multiplex assay system, and the results were compared with those observed in control macrophages. Expression levels of factors known to stimulate monocyte chemotaxis, including IL-6, MCP-1, KC, MIP- $1 \beta$, and RANTES, were significantly up-regulated in conditioned medium from TAMs (Figure 2A). In contrast, no marked cytokine expression was observed in conditioned medium from control macrophages.
Because of up-regulation of monokines in TAM cultures, whether TAMs induced migration of monocytic cells was examined. Transwell migration of monocytic RAW264.7 cells was increased in the presence of conditioned medium from control macrophages, and was further significantly enhanced in the presence of conditioned medium from TAMs (Figure 2B). These data indicate that the TAMs in EWS are "activated" macrophages that secrete a number of cytokines and chemokines and induce accumulation of monocytic cells.

Next examined was the effect of TAMs on vascular endothelial cell tube formation, a critical process during angiogenesis. The formation of tubelike structures by microvascular endothelial cells increased in response to conditioned medium from RD-ES cells, whereas no stimulatory effects were observed in the presence of conditioned medium from TAMs (data not shown).

\section{Osteoclastic Differentiation of TAMs in EWS}

Most EWS tumors arise in bone, and bone metastasis is often observed during the clinical course of these tumors. Because osteoclasts are critically involved in development of bone tumors, ${ }^{29}$ the potential contribution of TAMs to osteoclastogenesis in EWS was examined. To investigate their osteoclastic differentiation, TAMs were incubated for 4 days with soluble RANKL (sRANKL) and M-CSF, two factors crucial for osteoclastogenesis. ${ }^{30}$ In the absence of sRANKL and M-CSF, no TRAP-positive
A
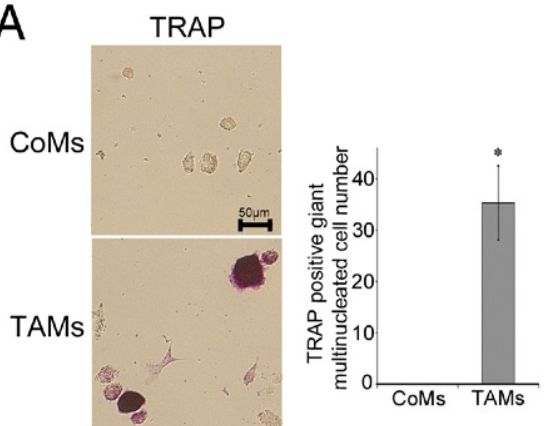

C
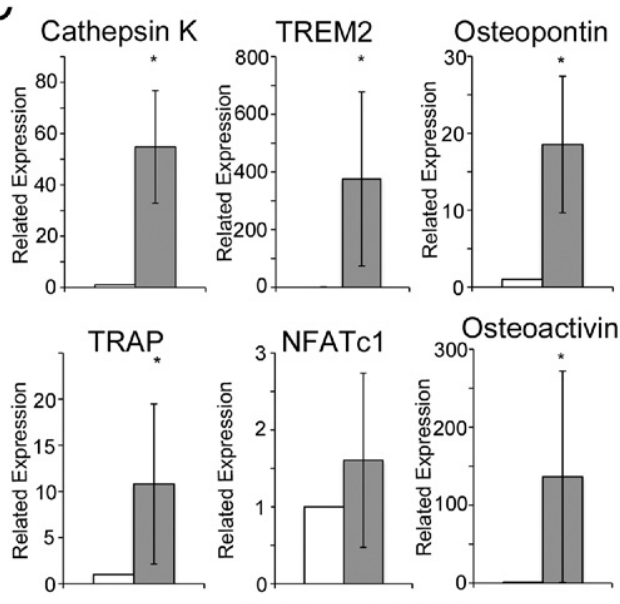

B

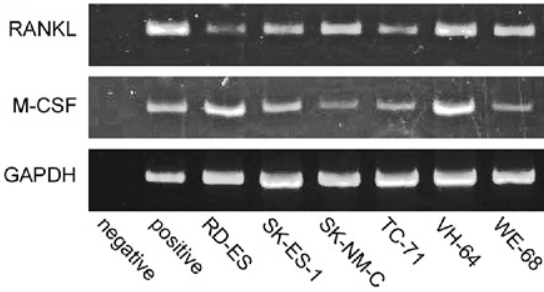

D

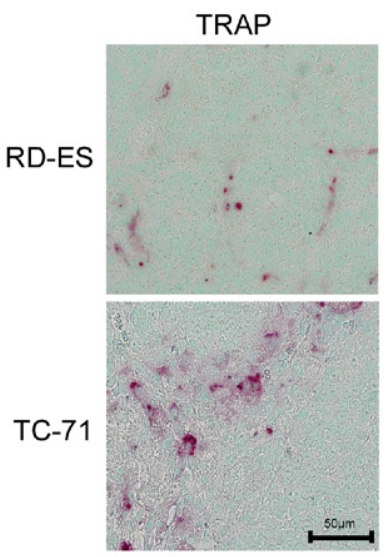

Figure 3. Osteoclastic differentiation of TAM in EWS. A: Induction of osteoclastic differentiation. TAMs or control macrophages were incubated with sRANKL and M-CSF for 4 days. Osteoclastic differentiation was visualized using TRAP staining (left). TRAP-positive multinucleated giant cells were counted (right). Results are given as mean $\pm \mathrm{SD} .{ }^{*} P<0.05$. B: RT-PCR was performed to detect the expression of RANKL and M-CSF mRNA in six EWS cell lines. C: Quantitative RT-PCR was performed to detect osteoclastic differentiation in $\mathrm{CD} 11 \mathrm{~b}^{+}$cells. All expression levels were normalized on the basis of expression of GAPDH. Data show the relative expression in TAMs (gray bars) compared with control macrophages (white bars). Results are given as mean $\pm \mathrm{SD}$. ${ }^{*} P<0.05$. D: TRAP staining of EWS xenografts that developed from RD-ES or TC-71 cells. Sections were counterstained with diluted methyl green solution. Scale bars: $20 \mu \mathrm{m}(\mathbf{A}) ; 50 \mu \mathrm{m}$ (D) 


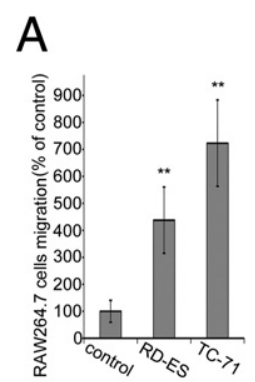

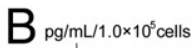

C

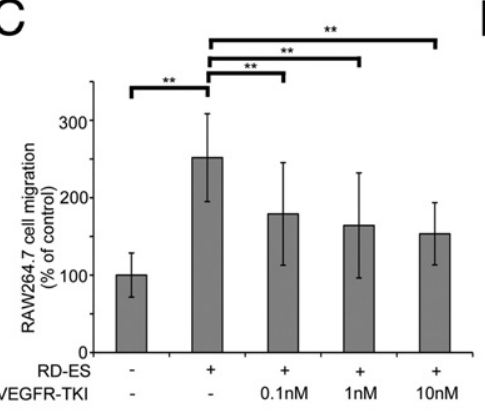

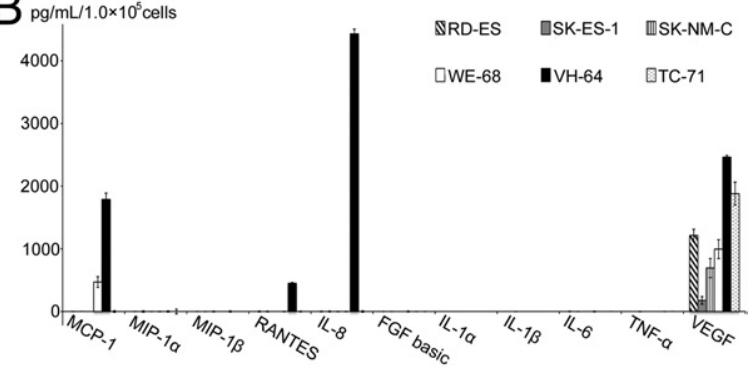

$D_{\text {pomm }}$

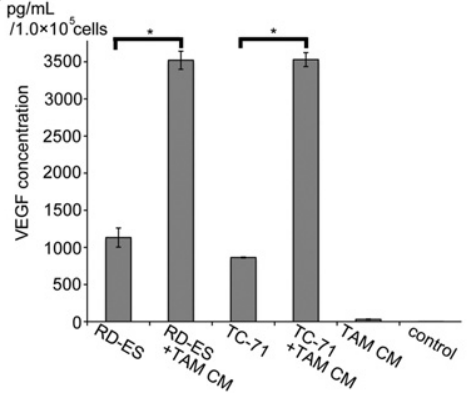

Figure 4. EWS cell lines stimulate monocyte migration via VEGF signaling. A: Migration of monocytic cells was examined using the Transwell system. The lower wells were filled with serum-free medium, RD-ES cells, or TC-71 cells, and RAW264.7 cell migration to the bottom surface of the Transwell was assessed. Results are given as mean \pm SD. ${ }^{* *} P<$ 0.01. B: The Luminex multiplex assay system was used to screen for chemotactic factors produced by EWS cells. C: Inhibitory effects of VEGFR-TKI on migration of RAW264.7 cells. RAW264.7 cells were co-cultured with RD-ES cells, and their migration to the bottom surface of the Transwell in the presence of VEGFR-TKI was assessed. Results are given as mean $\pm \mathrm{SD}$. ${ }^{* * *} P<0.01$. D: Quantification of VEGF secretion by EWS cells. RD-ES or TC-71 cells were stimulated with conditioned medium (CM) from TAMs for 48 hours, and the VEGF concentration in conditioned medium from EWS cells was examined using a human VEGF enzyme-linked immunosorbent assay kit. Serum-free DMEM was used as negative control. Results are given as mean \pm SD. ${ }^{*} P<0.05$.

giant cells were developed from either TAMs or control macrophages (see Supplemental Figure S2A at http:// ajp.amjpathol.org). However, in the presence of sRANKL and M-CSF, TRAP staining revealed formation of multinucleated giant cells only from TAMs, thereby demonstrating that TAMs are capable of differentiating into osteoclasts (Figure 3A; see also Supplemental Figure S2A at http://ajp.amjpathol.org). Significantly more TRAP-positive giant multinucleated cells were developed from TAMs than from control macrophages (Figure 3A).

To elucidate the mechanism involved in the enhanced osteoclastic differentiation of TAMs, expression of RANKL and M-CSF in EWS cells was examined. Some
EWS cell lines express RANKL ${ }^{24}$; however, the expression of M-CSF has not been reported in EWS. Both RANKL and M-CSF mRNA expression were detected in all six examined EWS cell lines (Figure 3B). TAMs freshly isolated from EWS expressed such osteoclastic markers as cathepsin $\mathrm{K}$, triggering receptor expressed on myeloid cells-2, osteopontin, TRAP, and osteoactivin (Figure $3 C)$. Examination of the cell smear of TAMs revealed that freshly isolated cells were mononuclear, and no giant cells were observed (see Supplemental Figure S2B at http://ajp.amjpathol.org). Although limited, TRAP activity was detected in some TAMs $(0.9 \%$ of the cells), whereas no TRAP-positive cells were observed in control macro-
A

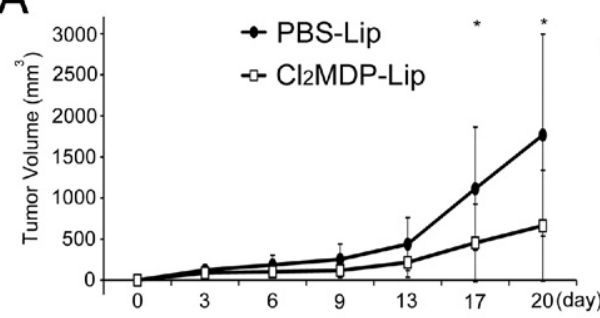

C

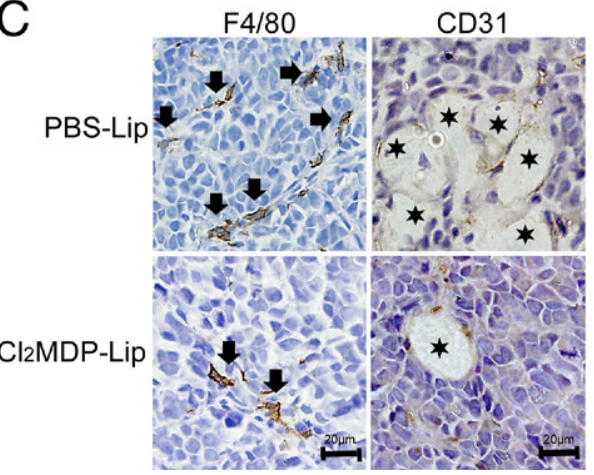

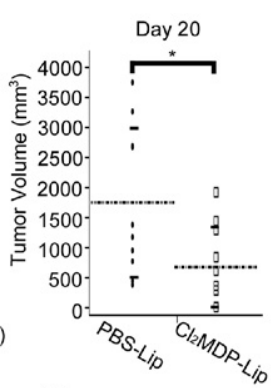

D

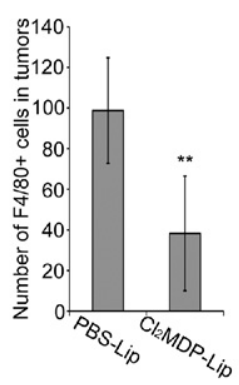

B

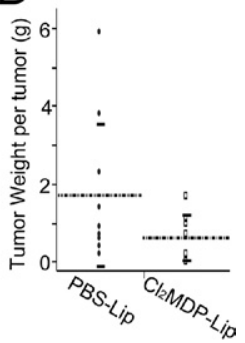

Figure 5. Effects of macrophage depletion in an EWS xenograft model. A: Left, $\mathrm{Cl}_{2}$ MDP-Lip (white squares) or PBS-Lip (black circles) was administered i.v. in nude mice 1 day before inoculation with RD-ES cells. Mice received $200 \mu \mathrm{L}$ liposomes through the tail vein every 3 days. Length and width of the tumors were measured for 3 weeks after inoculation. Right, Dot plot for tumor volumes at 20 days after inoculation. Tumor volumes in the group treated with $\mathrm{Cl}_{2} \mathrm{MDP}$-Lip were significantly lower than those in the PBS-Lip group. Five mice were used in each group. Results are given as mean (dotted lines) \pm SD (straight lines). ${ }^{*} P<0.05$. B: Tumors were excised and weighed at 3 weeks after inoculation. C: Immunohistochemical staining of macrophages and the tumor vasculature in EWS xenografts. Infiltrating macrophages (arrow) were visualized using anti-F4/80 antibodies (left). Tumor vasculature (asterisk) was visualized using anti-CD31 antibodies (right). Scale bars $=20$ $\mu \mathrm{m}$. D: Mean number of F4/80-positive macrophages and CD31-positive vessels in six random field profiles were used for subsequent statistical analyses (Mann-Whitney $U$-test). Results are given as mean $\pm \mathrm{SD}$. ${ }^{* * *} P<0.01$. 
phages (see Supplemental Figure S2B at http://ajp. amjpathol.org). TRAP activity was also clearly detected in mononuclear cells that invaded EWS subcutaneous xenografts even when these tumors had no contact with bone (Figure 3D). These observations suggest that some of the TAMs in EWS initiate osteoclastic differentiation within the tumor tissue.

\section{VEGF Recruits TAMs to EWS}

Next investigated were the potential mechanisms underlying recruitment of monocytes to EWS. Migration of RAW264.7 cells was significantly enhanced in co-cultures with RD-ES, TC-71 (Figure 4A), SK-N-MC, and SK-ES-1 (data not shown). Therefore, EWS cell lines were screened for potential monocyte chemoattractants. A cytokine multiplex assay revealed that VEGF was secreted by all six of the EWS cell lines examined (Figure 4B). VEGF induces migration of monocytic cells that express the VEGF receptor Flt-1. ${ }^{31}$ As demonstrated by Matsumoto et al, ${ }^{31}$ RAW264.7 cell migration was dose-dependently stimulated by VEGF (data not shown). Moreover, blocking VEGF receptor signaling reduced EWS-induced RAW264.7 cell migration by $65 \%$ (Figure 4C).
Because VEGF production is induced in various tumor cells by inflammatory stimuli, ${ }^{21}$ we cultured EWS cells with conditioned medium from TAMs and examined VEGF production using an enzyme-linked immunosorbent assay. Increased VEGF secretion was observed when the RD-ES or TC-71 cells were stimulated with conditioned medium from TAMs (Figure 4D). These results demonstrated that recruitment of TAMs to EWS depends, at least in part, on EWS-derived VEGF, the secretion of which is up-regulated in the presence of TAMs.

\section{Effects of Macrophage Depletion on Development of EWS Xenografts}

To investigate the involvement of TAMs in development of EWS, $\mathrm{Cl}_{2}$ MDP-Lip ${ }^{27,28}$ was used to decrease the number of monocytes and macrophages in mouse EWS xenografts. Compared with PBS-Lip, $\mathrm{Cl}_{2}$ MDP-Lip significantly inhibited development of xenografts (Figure 5A), whereas no inhibitory effects on proliferation of RD-ES cells were observed in vitro (data not shown). At 21 days after inoculation, xenografts were excised and examined. Although the changes were not significant, the average xenograft weight tended to be lower in mice treated with $\mathrm{Cl}_{2} \mathrm{MDP}$ -
A
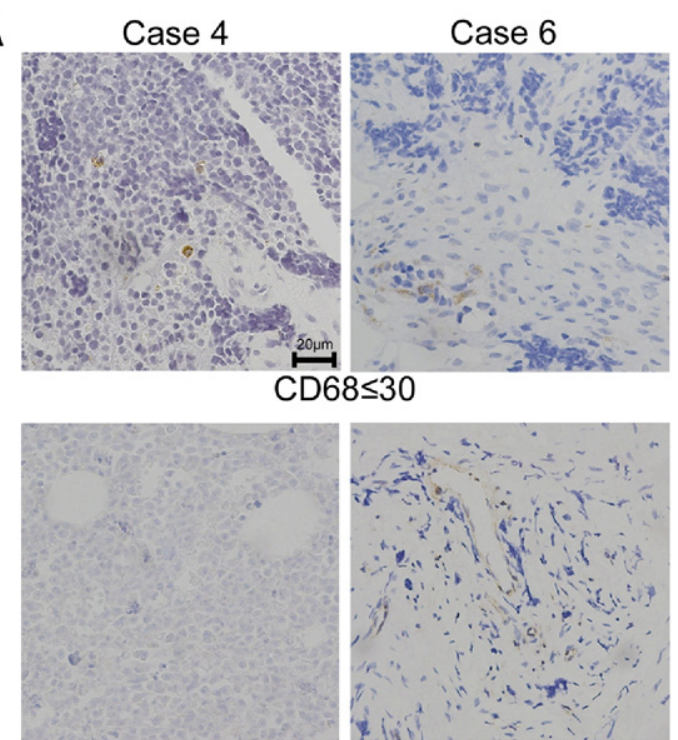

MVD $\leq 10$

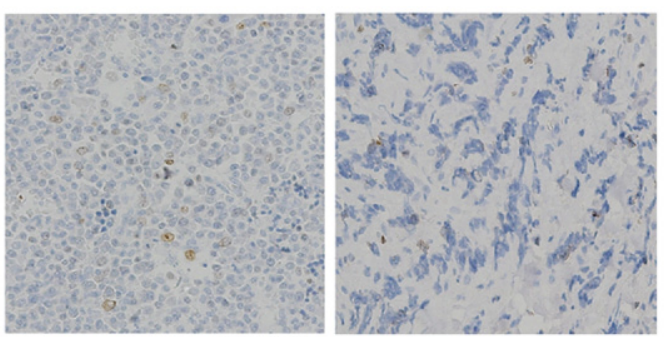

MIB1 index $<40$
B
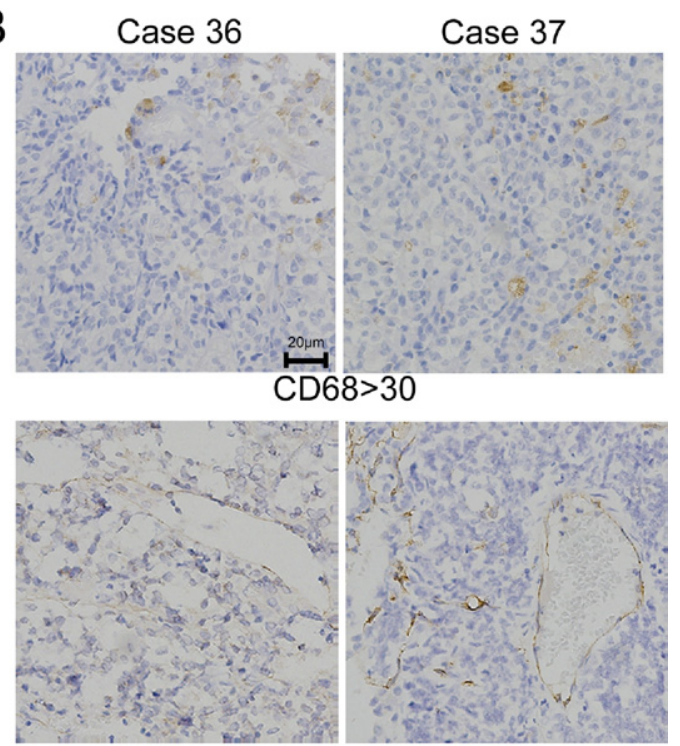

MVD $>10$

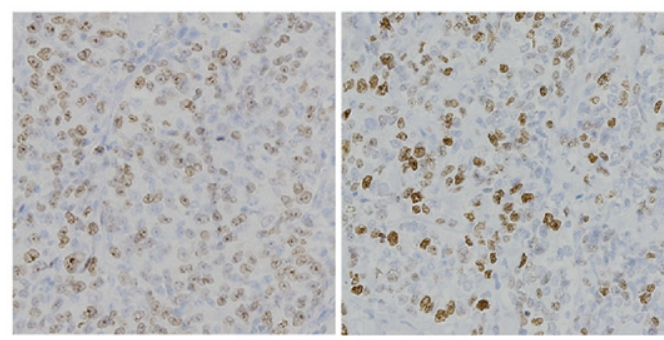

MIB1 index $\geq 40$

Figure 6. Immunohistochemical staining of human EWS sections. Representative staining of macrophages, tumor vasculature, and MIB1 in EWS samples. Paraffin sections were immunohistochemically stained using anti-CD68, anti-CD31, and anti-MIB1 antibodies, and were visualized using the diaminobenzidene substrate system. Counterstaining was then performed using diluted hematoxylin. Compared with cases with lower macrophage infiltration [ $\leq 30$ CD 68 cells/HPF; case 4 (continuously disease-free) and case 6 (no evidence of disease)] (A), prominent tumor microvasculature and MIB1 expression were evident in cases with higher macrophage infiltration (>30 CD68 cells/HPF; cases 36 and 37 died of disease) (B). Scale bars: $20 \mu \mathrm{m}$ (A and B). 
Lip (Figure 5B). Immunohistochemical analysis of mice treated with PBS-Lip revealed numerous F4/80-positive macrophages in the tumors, whereas fewer infiltrating macrophages were observed in tumors treated with $\mathrm{Cl}_{2}$ MDP-Lip (Figure 5, C and D). In addition, the tumor vasculature was significantly decreased in mice treated with $\mathrm{Cl}_{2} \mathrm{MDP}$-Lip (Figure 5, C and D), which suggests that inhibition of angiogenesis contributed to the decreased tumor growth.

\section{Association between Infiltrating Macrophages and Poor Clinical Outcome in EWS}

Whether infiltrating macrophages were associated with the clinical outcome in patients with EWS was investigated. Anti-CD68 antibodies were used to quantify the number of TAMs in EWS clinical samples. Representative images of EWS samples with CD68-positive tumor-infiltrating macrophages are shown in Figure 6, A and B. The signals were localized in the membrane and cytoplasm but not in the nucleus of these cells. To further confirm the identity of CD68-positive cells in EWS as macrophages, we performed double fluorescence immunostaining for CD68 and CD14 (see Supplemental Figure S3 at $h t t p: / /$ ajp.amjpathol.org). Examination of 10 different EWS clinical samples revealed that $97 \%$ of the CD68-positive cells were also positive for CD14, indicating that the CD68positive cells in EWS are macrophages.

Kaplan-Meier survival analysis was performed to determine the prognostic significance of TAMs and other clinical parameters in 41 EWS cases. Clinical characteristics of the cases are given in Table 3. A higher extent of macrophage infiltration [ $>30$ CD68 cells/high-power field $(\mathrm{HPF})])$ and greater microvascular density (>10/HPF; Figure $6, \mathrm{~A}$ and $\mathrm{B}$ ) were associated with poorer overall survival (Figure 7, A and B). In addition, elevated CRP $(>0.2 \mathrm{mg} / \mathrm{dL}$ ) and white blood cell (WBC) counts (>6800 cells $/ \mu \mathrm{L}$ ) were also associated with poorer prognosis (Figure 7, C and D). A higher macrophage infiltration rate was also significantly associated with higher microvascular density (odds ratio, 8; 95\% confidence interval, 1.9 to $33.2 ; P=0.0044$ ), elevated serum CRP (odds ratio, 16 ;

Table 3. Relationship between Tumor CD68 Expression and Clinicopathologic Characteristics of EWS

\begin{tabular}{|c|c|c|}
\hline \multirow[b]{2}{*}{ Variable } & \multicolumn{2}{|c|}{ No. of CD68 cells } \\
\hline & Low $(\leq 30)$ & High $(>30)$ \\
\hline Follow-up, range (median), months & $15-138(60.4)$ & $7-181(41.3)$ \\
\hline \multicolumn{3}{|l|}{ Sex } \\
\hline Male & 9 & 9 \\
\hline Female & 12 & 11 \\
\hline \multicolumn{3}{|l|}{ Age, years } \\
\hline$\leq 18$ & 12 & 9 \\
\hline$>18$ & 9 & 11 \\
\hline Range (median) & $5-68(23)$ & $8-74(23)$ \\
\hline \multicolumn{3}{|l|}{ Tumor location } \\
\hline Extremity & 9 & 8 \\
\hline Trunk & 12 & 12 \\
\hline \multicolumn{3}{|l|}{ Origin site } \\
\hline Skeletal & 10 & 11 \\
\hline Extraskeletal & 11 & 9 \\
\hline \multicolumn{3}{|l|}{ Metastasis at diagnosis } \\
\hline Bone & 1 & 2 \\
\hline Lung & 3 & 2 \\
\hline Bone and lung & 0 & 1 \\
\hline Other & 0 & 1 \\
\hline \multicolumn{3}{|l|}{ Tumor size, $\mathrm{cm}$} \\
\hline$<8$ & 12 & 7 \\
\hline$\geq 8$ & 9 & 13 \\
\hline \multicolumn{3}{|l|}{ CD31 vessel number } \\
\hline$\leq 10$ & 14 & 4 \\
\hline$>10$ & 7 & 16 \\
\hline \multicolumn{3}{|l|}{ Status } \\
\hline Continuously disease-free & 10 & 4 \\
\hline No evidence of disease & 1 & 0 \\
\hline Alive with disease & 4 & 0 \\
\hline Died of disease & 6 & 16 \\
\hline \multicolumn{3}{|l|}{ Systemic multiagent chemotherapy } \\
\hline Yes & 20 & 20 \\
\hline No & 1 (status: continuously disease-free) & 0 \\
\hline Surgery and/or radiation & 21 & 20 \\
\hline \multicolumn{3}{|c|}{ Initial laboratory measurements, range (median) } \\
\hline $\mathrm{CRP}, \mathrm{mg} / \mathrm{dL}$ & $0-3.5(0.5)$ & $0.1-27(6.4)$ \\
\hline WBC count, $/ \mu \mathrm{L}$ & $4010-12100(6507)$ & $3120-12570(7855)$ \\
\hline $\mathrm{LDH}, \mathrm{IU} / \mathrm{L}$ & $150-7100(613)$ & $235-4973(742)$ \\
\hline
\end{tabular}



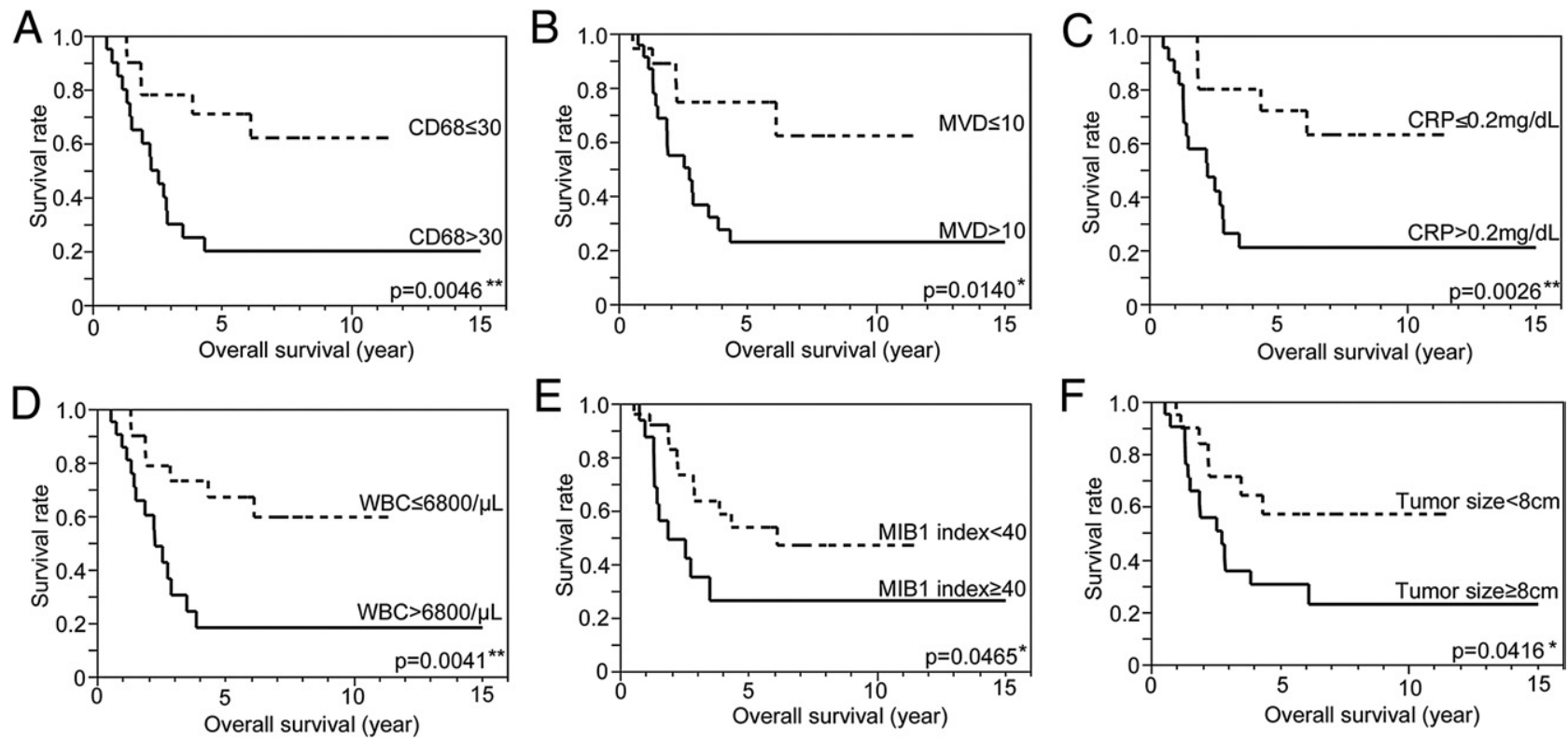

Figure 7. Association between macrophage infiltration and poor prognosis in EWS. A-F: Kaplan-Meier survival curves for all patients based on CD68-positive macrophage infiltration (low, $\leq 30 \mathrm{CD} 68$ cells/HPF; high, $>30$ CD68 cells/HPF) (A), microvascular density (low, $\leq 10 / \mathrm{HPF}$; high, $>10 / \mathrm{HPF})(\mathbf{B})$, serum CRP concentration (low, $\leq 0.2 \mathrm{mg} / \mathrm{dL}$; high, $>0.2 \mathrm{mg} / \mathrm{dL}$ ) (C), WBC counts (low, $\leq 6800$ cells $/ \mu \mathrm{L} ;$ high, $>6800$ cells $/ \mu \mathrm{L}$ ) (D), MIB1 expression (low MIB1 index, $<40$; high MIB1 index, $\geq 40)(\mathbf{E})$, and tumor size (small, $<8 \mathrm{~cm}$; large, $\geq 8)(\mathbf{F})$. Log-rank tests were performed to determine statistical significance, with $P<0.05$ defined as significant. ${ }^{*} P<0.05$. ${ }^{* *} P<0.01$.

95\% confidence interval, 3.2 to $78.3 ; P=0.0003)$, and WBC counts (odds ratio, $8 ; 95 \%$ confidence interval, 1.9 to $30.0 ; P=0.0048$ ) (Table 4). Neither the serum concentration of CRP nor the WBC counts correlated with tumor size (data not shown). As reported previously, more frequent MIB1 expression (MIB1 index $\geq 40$; Figure $6 \mathrm{~B})$ and larger tumor size $(\geq 8 \mathrm{~cm})$ were significantly associated with poorer prognosis (Figure $7, \mathrm{E}$ and F). ${ }^{1,32,33}$ In addition, increased serum lactate dehydrogenase concentration ( $>340 \mathrm{IU} / \mathrm{L}$ ) tended to be associated with poor prognosis, although statistical significance was not observed (data not shown). Age 18 years or younger, sex, and tumor position were not associated with overall survival (data not shown). Also performed were univariate and multivariate analyses with variables including the number of CD68 cells, tumor size, and treatment with multiple-agent chemotherapy. At multivariate analysis, CRP concentration, WBC counts, and mi- crovascular density were excluded from the variables because of their strong association with the number of CD68 cells (Table 5). Both the number of CD68 cells and tumor size were identified as significant factors at univariate analysis; however, at multivariate analysis, only the number of CD68 cells remained a significant predictor of poor prognosis (Table 5).

\section{Discussion}

Through production of growth factors, cytokines and chemokines, and proteases, TAMs have an important role in tumor invasion, angiogenesis, and metastasis. ${ }^{34,35}$ Infiltrating TAMs were observed to be associated with systemic inflammation, enhanced tumor vasculature, and poor clinical outcome in patients with EWS, which suggests that TAMs could be used as a prognostic factor for

Table 4. Factors Associated with Macrophage Infiltration

\begin{tabular}{|c|c|c|c|c|c|}
\hline \multirow[b]{2}{*}{ Associated factors } & \multicolumn{2}{|c|}{ No. of CD68 cells } & \multirow[b]{2}{*}{ OR } & \multirow[b]{2}{*}{$95 \% \mathrm{Cl}$} & \multirow[b]{2}{*}{$P$ value* } \\
\hline & $\operatorname{Low}(\leq 30)$ & High $(>30)$ & & & \\
\hline \multicolumn{6}{|l|}{ CD31 vessel numbers } \\
\hline$\leq 10$ & 14 & 4 & 8 & 1.9 to 33.2 & 0.0044 \\
\hline$>10$ & 7 & 16 & & & \\
\hline \multicolumn{6}{|c|}{ Serum CRP concentration, mg/dL } \\
\hline$\leq 0.2$ & 17 & 3 & 16 & 3.2 to 78.3 & 0.0003 \\
\hline$>0.2$ & 5 & 17 & & & \\
\hline \multicolumn{6}{|l|}{ WBC count, $/ \mu \mathrm{L}$} \\
\hline$\leq 6800$ & 15 & 5 & 8 & 1.9 to 30.0 & 0.0048 \\
\hline$>6800$ & 6 & 15 & & & \\
\hline
\end{tabular}

*Fisher's exact test $(P<0.01)$.

$\mathrm{Cl}$, confidence interval; CRP, C-reactive protein; OR, odds ratio; WBC, white blood cell. 
Table 5. Results of Univariate and Multivariate Analyses for Overall Survival

\begin{tabular}{|c|c|c|c|c|}
\hline \multirow[b]{2}{*}{ Variable } & \multicolumn{2}{|c|}{$\begin{array}{l}\text { Univariate } \\
\text { analysis }\end{array}$} & \multicolumn{2}{|c|}{$\begin{array}{c}\text { Multivariate } \\
\text { analysis }\end{array}$} \\
\hline & $\begin{array}{l}\text { Hazard } \\
\text { ratio }\end{array}$ & $P$ value & $\begin{array}{l}\text { Hazard } \\
\text { ratio }\end{array}$ & $P$ value \\
\hline \multicolumn{5}{|l|}{ CD68 numbers } \\
\hline Low $(\leq 30)$ & 0.2772 & $0.0044^{*}$ & 0.3400 & $0.0235^{\dagger}$ \\
\hline High $(>30)$ & 1 & & 1 & \\
\hline \multicolumn{5}{|l|}{ Tumor size, $\mathrm{cm}$} \\
\hline$<8$ & 0.4045 & $0.0403^{\dagger}$ & 0.5804 & 0.2447 \\
\hline \multirow{2}{*}{\multicolumn{5}{|c|}{$\begin{array}{l}\text { Multiagent } \\
\text { chemotherapy }\end{array}$}} \\
\hline & & & & \\
\hline VDC-IE $(n=11)$ & 0.9521 & 0.9301 & 1.1129 & 0.8528 \\
\hline Other $(n=29)$ & & & 1 & \\
\hline
\end{tabular}

${ }^{*} P<0.01$.

${ }^{\dagger} P<0.05$.

‡Except surgery alone. side.

VDC-IE, vincristine-doxorubicin-cyclophosphamide-ifosfamide-etopo-

this family of tumors (Figure 8). The prognostic importance of high infiltration of TAMs in EWS was also confirmed at multivariate analysis (Table 5). Consistent with previous reports, ${ }^{24,36}$ compared with control macrophages, TAMs isolated from EWS xenografts exhibited a number of distinctive characteristics insofar as cytokine production and osteoclastogenesis. To our knowledge, this is the first report of the association between poor prognosis and the biological properties of TAMs in EWS.

Tumor-host immune interactions within the tumor microenvironment may modulate tumor progression, and both tumor-protective and tumor-promoting features of the immune response have been described. ${ }^{37}$ Insofar as the protective effects, tumor-infiltrating $T$ cells have been reported to be associated with a favorable prognosis in EWS, ${ }^{9}$ and various studies have been undertaken to develop immunotherapeutic strategies for EWS of advanced stage. ${ }^{38-40}$ The association of inflammation with tumor progression has also been well-documented in several tumor types, ${ }^{41}$ and TAMs are thought to be major regulators of inflammation in various tumors. ${ }^{35}$ Elevated serologic inflammatory markers such as CRP concentration and WBC counts are characteristic of EWS. ${ }^{1,32,42}$ Although both elevated CRP concentration and WBC counts were significantly associated with higher infiltration of TAMs (Table 4), the squared correlation coefficients $\left(R^{2}\right)$ were relatively small at 0.17 and 0.28 , respectively (data not shown), thereby indicating no obvious correlations between TAMs and the serum serologic inflammatory markers. This suggests that other factors such as lymphocytes may be involved in development of inflammation in EWS. ${ }^{9}$ Further studies are required to better understand the role of inflammatory cells during progression of EWS.

Factors in serum are useful as diagnostic and/or prognostic markers. Bacci et al ${ }^{43}$ examined 579 EWS cases and reported an association between serum lactic dehydrogenase concentration and prognosis. Although we noted that a higher lactic dehydrogenase concentration may be predictive of poorer prognosis, no statistically significant association was observed, probably because of the relatively smaller number of cases $(n=41)$ evaluated in our study. Rather, elevated serum CRP concentration and WBC counts were significantly associated with poorer prognosis, providing potential new prognostic markers that can be easily obtained in the clinical setting.

Tumor angiogenesis is often a limiting factor for tumor growth and metastasis and correlates with poor prognosis in carcinomas of the breast, bladder, and cervix. ${ }^{14,16,18}$ For EWS, Mikulic et al ${ }^{44}$ examined 27 EWS cases and reported that lower microvascular density was associated with a tendency toward better outcome, although their results were not statistically significant. In addition to regular blood vessels, EWS tumor cells have also been reported to contribute to increased tumor blood supply and to be associated with poor prognosis by forming a vascular-like tube formation via endoglin signaling. ${ }^{45,46}$ In the present study, a significant association was observed between infiltrating macrophages and microvascular density in 41 EWS cases (Figure 6, A and $\mathrm{B}$; Table 4). Decreasing the macrophage numbers using $\mathrm{Cl}_{2} \mathrm{MDP}$ reduced tumor vascularity and slowed tumor growth in mouse EWS xenografts (Figure 5, A-D). Although TAMs in EWS did not directly stimulate endothelial tube formation (data not shown), they significantly stimulated EWS to produce VEGF (Figure 4D), one of the most potent inducers of angiogenesis. This observation suggests that TAMs in EWS indirectly promote angiogenesis by stimulating VEGF production from EWS tumor cells, thus resulting in tumor progression (Figure 8).

VEGF has an indispensable role in the growth of EWS. Small interfering RNA targeting VEGF has been used to inhibit EWS growth in a xenograft mouse model ${ }^{47} \mathrm{Com}$ pared with healthy control subjects, patients with EWS demonstrate increased serum VEGF concentrations, ${ }^{48}$ and histologic evaluation revealed that elevated VEGF expression in EWS correlates with poorer clinical outcome. ${ }^{49}$ Although both macrophages and tumor cells can be a source of VEGF, ${ }^{50}$ we observed no detectable

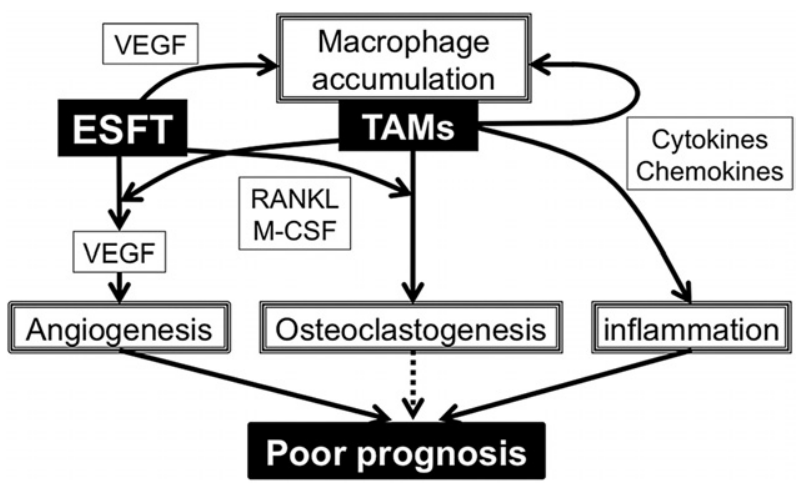

Figure 8. Model for TAM-mediated modulation of EWS microenvironment TAMs have important roles as modulators of inflammation, angiogenesis, and osteoclastogenesis during EWS development. TAMs accumulation is mediated by VEGF secretion from EWS, and is further enhanced by various cytokines and chemokines released from the TAMs themselves, resulting in an inflammatory reaction in EWS. TAMs stimulate tumor angiogenesis by enhancing VEGF production from tumor cells, resulting in a poorer prognosis. Enhanced osteoclastogenesis induced by TAMs enhances bone tumor progression and may affect the prognosis in EWS. 
VEGF production from TAMs in EWS (Figure 2A). This may explain why conditioned medium from TAMs did not stimulate proliferation or tube formation by endothelial cells, two activities that primarily depend on VEGF. ${ }^{51}$ Activated macrophages produce inflammatory cytokines such as IL-1 and MCP-1, which can enhance VEGF production by tumor cells. ${ }^{21,26,52,53}$ These reports, in concert with the present observations, suggest that angiogenesis in EWS is predominantly regulated by EWS-derived VEGF, the expression of which is significantly up-regulated in the presence of TAMs (Figure 4D).

The detailed mechanisms underlying macrophage accumulation in EWS are not clear. VEGF may have a role in the initial recruitment of TAMs because EWS-induced migration of monocytic RAW264.7 cells was significantly reduced in the presence of a VEGF receptor inhibitor (Figure 4C). VEGF stimulates monocyte migration via the Flt-1 receptor signaling pathway ${ }^{31}$ and contributes to accumulation of TAMs in breast cancer. ${ }^{54} \mathrm{~A}$ recent report revealed that VEGF expression was up-regulated by an EWS/FLI1 fusion gene, ${ }^{55}$ which may explain why VEGF was secreted by all six of the EWS cell lines examined in the present study (Figure 4B).

In addition to VEGF, cytokines and chemokines have important roles in accumulation of TAMs. Expression levels of MCP-1, MIP-1, and RANTES correlate with the number of TAMs in various cancers. ${ }^{56}$ These monocyte and macrophage chemoattractants are produced not only by tumor cells but also by stromal cells including macrophages. ${ }^{6}$ TAMs in EWS expressed several soluble inflammatory factors including IL-6, GRO1 (mouse keratinocyte-derived chemokine), MCP-1, MIP-1 $\beta$, and RANTES (Figure 2A), all of which are capable of stimulating monocyte chemotaxis. ${ }^{57-61}$ These factors may contribute to recruitment and accumulation of macrophages in EWS in an autocrine or paracrine manner. In addition to recruiting macrophages, cytokines and chemokines regulate development of the tumor microenvironment. For example, GRO1 has been implicated in regulating stromal fibroblasts during ovarian tumorigenesis ${ }^{62}$ and promoting breast cancer metastasis. ${ }^{63}$ RANTES, secreted from mesenchymal stem cells in tumors, reportedly promotes breast cancer metastasis. ${ }^{6} \mathrm{MCP}-1$ regulates angiogenesis in gastric cancer via macrophage recruitment. ${ }^{64}$ The roles of these factors during development of EWS require further elucidation.

During bone tumor development, bone matrix is absorbed and degraded primarily by osteoclasts, ${ }^{29}$ which are specialized cells differentiated from peripheral circulation- or bone marrow-derived monocytic cells. Serum TRACP $5 b$ concentration and the presence of active osteoclasts are positively associated with the aggressiveness of primary osteosarcoma. ${ }^{65}$ Lau et $\mathrm{al}^{24}$ reported that TAMs in EWS arising in bone are capable of differentiating into osteoclasts via both RANKL-dependent and RANKL-independent pathways. Compared with control macrophages, TAMs exhibited enhanced osteoclastogenesis (Figure $3 \mathrm{~A}$ ), which suggests that TAMs may promote both tumor progression and osteolysis in EWS.

In addition, we detected expression of the osteoclastic markers cathepsin K, TREM2, osteoactivin, and osteo- pontin in TAMs (Figure 3C), which suggests that osteoclastic differentiation had been initiated in this cell population, possibly as a result of the expression of RANKL and M-CSF by EWS cells (Figure 3B). VEGF may enhance osteoclastogenesis by up-regulating not only RANKL in EWS but also RANK in osteoclast precursor cells. ${ }^{66}$ Furthermore, various factors secreted by TAMs including IL-6, MCP-1, MIP-1 $\beta$, and RANTES may also enhance osteoclastic differentiation in an autocrine manner. ${ }^{58,59,67-69}$ Cathepsin $\mathrm{K}$ and osteoactivin have been reported to promote breast tumor progression. ${ }^{70,71}$ TAMs are reported to express osteoactivin, which could be speculatively linked to a tumor tissue remodeling function and matrix metalloproteinase activation. ${ }^{35}$ Osteopontin is reportedly involved in the progression of various tumors such as prostate, lung, breast, and pancreatic cancers and hepatocellular carcinoma. ${ }^{72,73}$ Increased expression of cathepsin K, osteoactivin, and osteopontin in TAMs may also have a role in progression of EWS.

In conclusion, the present study revealed a significant association between macrophage infiltration in EWS and clinical outcome. TAMs seem to enhance the progression of EWS by stimulating both angiogenesis and osteoclastogenesis, processes mediated by various cytokines and chemokines (Figure 8). TAMs and the various factors that they produce may provide new therapeutic targets for EWS.

\section{References}

1. Iwamoto Y: Diagnosis and treatment of Ewing's sarcoma. Jpn J Clin Oncol 2007, 37:79-89

2. Tow BP, Tan MH: Delayed diagnosis of Ewing's sarcoma of the right humerus initially treated as chronic osteomyelitis: a case report. J Orthop Surg (Hong Kong) 2005, 13:88-92

3. Balkwill F, Mantovani A: Inflammation and cancer: back to Virchow? Lancet 2001, 357:539-545

4. Pietras K, Ostman A: Hallmarks of cancer: interactions with the tumor stroma. Exp Cell Res 2010, 316:1324-1331

5. Cortes-Funes $\mathrm{H}$ : The role of antiangiogenesis therapy: bevacizumab and beyond. Clin Transl Oncol 2009, 11:349-355

6. Karnoub AE, Dash AB, Vo AP, Sullivan A, Brooks MW, Bell GW Richardson AL, Polyak K, Tubo R, Weinberg RA: Mesenchymal stem cells within tumour stroma promote breast cancer metastasis. Nature 2007, 449:557-563

7. Queen MM, Ryan RE, Holzer RG, Keller-Peck CR, Jorcyk CL: Breast cancer cells stimulate neutrophils to produce oncostatin $\mathrm{M}$ : potential implications for tumor progression. Cancer Res 2005, 65:8896-8904

8. Silzle T, Randolph GJ, Kreutz M, Kunz-Schughart LA: The fibroblast: sentinel cell and local immune modulator in tumor tissue. Int $\mathrm{J}$ Cancer 2004, 108:173-180

9. Berghuis D, Santos SJ, Baelde HJ, Taminiau AH, Maarten Egeler R, Schilham MW, Hogendoorn PC, Lankester AC: Pro-inflammatory chemokine-chemokine receptor interactions within the Ewing sarcoma microenvironment determine CD8(+) T-lymphocyte infiltration and affect tumour progression. J Pathol 2011, 223:347-357

10. Ono M: Molecular links between tumor angiogenesis and inflammation: inflammatory stimuli of macrophages and cancer cells as targets for therapeutic strategy. Cancer Sci 2008, 99:1501-1506

11. Allavena P, Sica A, Garlanda C, Mantovani A: The Yin-Yang of tumorassociated macrophages in neoplastic progression and immune surveillance. Immunol Rev 2008, 222:155-161

12. Mantovani A, Bottazzi B, Colotta F, Sozzani S, Ruco L: The origin and function of tumor-associated macrophages. Immunol Today 1992 13:265-270

13. Polverini PJ: Role of the macrophage in angiogenesis-dependent diseases. EXS 1997, 79:11-28 
14. Leek RD, Lewis CE, Whitehouse R, Greenall M, Clarke J, Harris AL: Association of macrophage infiltration with angiogenesis and prognosis in invasive breast carcinoma. Cancer Res 1996, 56:4625-4629

15. Shimura S, Yang G, Ebara S, Wheeler TM, Frolov A, Thompson TC: Reduced infiltration of tumor-associated macrophages in human prostate cancer: association with cancer progression. Cancer Res 2000, 60:5857-5861

16. Hanada T, Nakagawa M, Emoto A, Nomura T, Nasu N, Nomura Y Prognostic value of tumor-associated macrophage count in human bladder cancer. Int J Urol 2000, 7:263-269

17. Davidson SE, West CM, Hunter RD: Lack of association between in vitro clonogenic growth of human cervical carcinoma and tumour stage, differentiation, patient age, host cell infiltration or patient survival. Int J Cancer 1992, 50:10-14

18. Fujimoto J, Sakaguchi H, Aoki I, Tamaya T: Clinical implications of expression of interleukin 8 related to angiogenesis in uterine cervical cancers. Cancer Res 2000, 60:2632-2635

19. van Dongen $M$, Savage ND, Jordanova ES, Briaire-de Bruijn $I H$, Walburg KV, Ottenhoff TH, Hogendoorn PC, van der Burg SH, Gelderblom $\mathrm{H}$, van Hall $\mathrm{T}$ : Anti-inflammatory $\mathrm{M} 2$ type macrophages characterize metastasized and tyrosine kinase inhibitor-treated gastrointestinal stromal tumors. Int J Cancer 2010, 127:899-909

20. Nishie A, Ono M, Shono T, Fukushi J, Otsubo M, Onoue H, Ito $Y$, Inamura $\mathrm{T}$, Ikezaki K, Fukui M, Iwaki T, Kuwano M: Macrophage infiltration and heme oxygenase-1 expression correlate with angiogenesis in human gliomas. Clin Cancer Res 1999, 5:1107-1113

21. Torisu H, Ono M, Kiryu H, Furue M, Ohmoto $Y$, Nakayama J, Nishioka Y, Sone S, Kuwano M: Macrophage infiltration correlates with tumor stage and angiogenesis in human malignant melanoma: possible involvement of TNFalpha and IL-1alpha. Int J Cancer 2000, 85:182-188

22. Meyers PA, Schwartz CL, Krailo MD, Healey JH, Bernstein ML, Betcher D, Ferguson WS, Gebhardt MC, Goorin AM, Harris M, Kleinerman E, Link MP, Nadel H, Nieder M, Siegal GP, Weiner MA, Wells RJ, Womer RB, Grier HE; Children's Oncology Group: Osteosarcoma: the addition of muramyl tripeptide to chemotherapy improves overal survival: a report from the Children's Oncology Group. J Clin Oncol 2008, 26:633-638

23. Buddingh EP, Kuijjer ML, Duim RA, Burger H, Agelopoulos K, Myklebost O, Serra M, Mertens F, Hogendoorn PC, Lankester AC, CletonJansen AM: Tumor-infiltrating macrophages are associated with metastasis suppression in high-grade osteosarcoma: a rationale for treatment with macrophage activating agents. Clin Cancer Res 2011 , 17:2110-2119

24. Lau YS, Adamopoulos IE, Sabokbar A, Giele H, Gibbons CL, Athanasou NA: Cellular and humoral mechanisms of osteoclast formation in Ewing's sarcoma. Br J Cancer 2007, 96:1716-1722

25. Kamura S, Matsumoto Y, Fukushi JI, Fujiwara T, lida K, Okada Y, Iwamoto $\mathrm{Y}$ : Basic fibroblast growth factor in the bone microenvironment enhances cell motility and invasion of Ewing's sarcoma family of tumours by activating the FGFR1-PI3K-Rac1 pathway. $\mathrm{Br} \mathrm{J}$ Cancer 2010, 103:370-381

26. Nakao S, Kuwano T, Tsutsumi-Miyahara C, Ueda S, Kimura YN, Hamano S, Sonoda KH, Saijo Y, Nukiwa T, Strieter RM, Ishibashi T, Kuwano M, Ono M: Infiltration of COX-2-expressing macrophages is a prerequisite for $\mathrm{IL}-1$ beta-induced neovascularization and tumor growth. J Clin Invest 2005, 115:2979-2991

27. Watari K, Nakao S, Fotovati A, Basaki Y, Hosoi F, Bereczky B, Higuch R, Miyamoto T, Kuwano M, Ono M: Role of macrophages in inflammatory lymphangiogenesis: enhanced production of vascular endothelial growth factor $\mathrm{C}$ and $\mathrm{D}$ through NF-kappaB activation. Biochem Biophys Res Commun 2008, 377:826-831

28. Hiraoka K, Zenmyo M, Watari K, Iguchi H, Fotovati A, Kimura YN Hosoi F, Shoda T, Nagata K, Osada H, Ono M, Kuwano M: Inhibition of bone and muscle metastases of lung cancer cells by a decrease in the number of monocytes/macrophages. Cancer Sci 2008, 99:15951602

29. Roodman GD: Mechanisms of bone metastasis. N Engl J Med 2004 350:1655-1664

30. Boyle WJ, Simonet WS, Lacey DL: Osteoclast differentiation and activation. Nature 2003, 423:337-342

31. Matsumoto Y, Tanaka K, Hirata G, Hanada M, Matsuda S, Shuto T, Iwamoto Y: Possible involvement of the vascular endothelial growth factor-Flt-1-focal adhesion kinase pathway in chemotaxis and the cell proliferation of osteoclast precursor cells in arthritic joints. J Immunol 2002, 168:5824-5831

32. Maheshwari AV, Cheng EY: Ewing sarcoma family of tumors. J Am Acad Orthop Surg 2010, 18:94-107

33. Lopez-Guerrero JA, Machado I, Scotlandi K, Noguera R, Pellin A, Navarro S, Serra M, Calabuig-Farinas S, Picci P, Llombart-Bosch A: Clinicopathological significance of cell cycle regulation markers in a large series of genetically confirmed Ewing's sarcoma family of tumors. Int J Cancer 2010, 128:1139-50

34. Mantovani A, Allavena P, Sica A, Balkwill F: Cancer-related inflammation. Nature 2008, 454:436-444

35. Solinas G, Germano G, Mantovani A, Allavena P: Tumor-associated macrophages (TAM) as major players of the cancer-related inflammation. J Leukoc Biol 2009, 86:1065-1073

36. Ojalvo LS, King W, Cox D, Pollard JW: High-density gene expression analysis of tumor-associated macrophages from mouse mammary tumors. Am J Pathol 2009, 174:1048-1064

37. de Visser KE: Spontaneous immune responses to sporadic tumors: tumor-promoting, tumor-protective or both? Cancer Immunol Immunother 2008, 57:1531-1539

38. Berghuis D, de Hooge AS, Santos SJ, Horst D, Wiertz EJ, van Eggermond MC, van den Elsen PJ, Taminiau AH, Ottaviano L, Schaefer KL, Dirksen U, Hooijberg E, Mulder A, Melief CJ, Egeler RM, Schilham MW, Jordanova ES, Hogendoorn PC, Lankester AC: Reduced human leukocyte antigen expression in advanced-stage Ewing sarcoma: implications for immune recognition. J Pathol 2009, 218:222-231

39. Verhoeven DH, de Hooge AS, Mooiman EC, Santos SJ, ten Dam MM, Gelderblom H, Melief CJ, Hogendoorn PC, Egeler RM, van Tol MJ, Schilham MW, Lankester AC: NK cells recognize and lyse Ewing sarcoma cells through NKG2D and DNAM-1 receptor dependent pathways. Mol Immunol 2008, 45:3917-3925

40. de Hooge AS, Berghuis D, Santos SJ, Mooiman E, Romeo S, Kummer JA, Egeler RM, van Tol MJ, Melief CJ, Hogendoorn PC, Lankester AC: Expression of cellular FLICE inhibitory protein, caspase-8, and protease inhibitor-9 in Ewing sarcoma and implications for susceptibility to cytotoxic pathways. Clin Cancer Res 2007, 13:206-214

41. Coussens LM, Werb Z: Inflammation and cancer. Nature 2002, 420: 860-867

42. Goto T, Hozumi T, Kondo T: Ewing's sarcoma. Gan To Kagaku Ryoho 2004, 31:346-350

43. Bacci G, Longhi A, Ferrari S, Mercuri M, Versari M, Bertoni F: Prognostic factors in non-metastatic Ewing's sarcoma tumor of bone: an analysis of 579 patients treated at a single institution with adjuvant or neoadjuvant chemotherapy between 1972 and 1998. Acta Oncol 2006, 45:469-475

44. Mikulic D, Ilic I, Cepulic M, Giljevic JS, Orlic D, Zupancic B, Fattorini I, Seiwerth S: Angiogenesis and Ewing sarcoma: relationship to pulmonary metastasis and survival. J Pediatr Surg 2006, 41:524-529

45. Pardali E, van der Schaft DW, Wiercinska E, Gorter A, Hogendoorn PC, Griffioen AW, ten Dijke P: Critical role of endoglin in tumor cell plasticity of Ewing sarcoma and melanoma. Oncogene 2011, 30: 334-345

46. van der Schaft DW, Hillen F, Pauwels P, Kirschmann DA, Castermans K, Egbrink MG, Tran MG, Sciot R, Hauben E, Hogendoorn PC, Delattre $\mathrm{O}$, Maxwell $\mathrm{PH}$, Hendrix MJ, Griffioen AW: Tumor cell plasticity in Ewing sarcoma, an alternative circulatory system stimulated by hypoxia. Cancer Res 2005, 65:11520-11528

47. Guan H, Zhou Z, Wang H, Jia SF, Liu W, Kleinerman ES: A small interfering RNA targeting vascular endothelial growth factor inhibits Ewing's sarcoma growth in a xenograft mouse model. Clin Cancer Res 2005, 11:2662-2669

48. Holzer G, Obermair A, Koschat M, Preyer O, Kotz R, Trieb K: Concentration of vascular endothelial growth factor (VEGF) in the serum of patients with malignant bone tumors. Med Pediatr Oncol 2001, 36:601-604

49. Fuchs B, Inwards CY, Janknecht R: Vascular endothelial growth factor expression is up-regulated by EWS-ETS oncoproteins and Sp1 and may represent an independent predictor of survival in Ewing's sarcoma. Clin Cancer Res 2004, 10:1344-1353

50. Sunderkotter C, Goebeler M, Schulze-Osthoff K, Bhardwaj R, Sorg C: Macrophage-derived angiogenesis factors. Pharmacol Ther 1991, 51:195-216 
51. Bishop ET, Bell GT, Bloor S, Broom IJ, Hendry NF, Wheatley DN: An in vitro model of angiogenesis: basic features. Angiogenesis 1999, 3:335-344

52. Ueno T, Toi M, Saji H, Muta M, Bando H, Kuroi K, Koike M, Inadera H, Matsushima K: Significance of macrophage chemoattractant protein-1 in macrophage recruitment, angiogenesis, and survival in human breast cancer. Clin Cancer Res 2000, 6:3282-3289

53. Futagami S, Tatsuguchi A, Hiratsuka T, Shindo T, Horie A, Hamamoto T, Ueki N, Kusunoki M, Miyake K, Gudis K, Tsukui T, Sakamoto C: Monocyte chemoattractant protein 1 and CD40 ligation have a synergistic effect on vascular endothelial growth factor production through cyclooxygenase 2 upregulation in gastric cancer. J Gastroenterol 2008, 43:216-224

54. Leek RD, Hunt NC, Landers RJ, Lewis CE, Royds JA, Harris AL: Macrophage infiltration is associated with VEGF and EGFR expression in breast cancer. J Pathol 2000, 190:430-436

55. Nagano A, Ohno T, Shimizu K, Hara A, Yamamoto T, Kawai G, Saitou M, Takigami I, Matsuhashi A, Yamada K, Takei Y: EWS/Fli-1 chimeric fusion gene upregulates vascular endothelial growth factor-A. Int $J$ Cancer 2010, 126:2790-2798

56. Jin G, Kawsar HI, Hirsch SA, Zeng C, Jia X, Feng Z, Ghosh SK, Zheng QY, Zhou A, Mclntyre TM, Weinberg A: An antimicrobial peptide regulates tumor-associated macrophage trafficking via the chemokine receptor CCR2, a model for tumorigenesis. PLoS One 2010, 5:e10993

57. Clahsen T, Schaper F: Interleukin-6 acts in the fashion of a classical chemokine on monocytic cells by inducing integrin activation, cell adhesion, actin polymerization, chemotaxis, and transmigration. J Leukoc Biol 2008, 84:1521-1529

58. Ishida N, Hayashi K, Hattori A, Yogo K, Kimura T, Takeya T: CCR1 acts downstream of NFAT2 in osteoclastogenesis and enhances cell migration. J Bone Miner Res 2006, 21:48-57

59. Onan D, Allan EH, Quinn JM, Gooi JH, Pompolo S, Sims NA, Gillespie MT, Martin TJ: The chemokine Cxcl1 is a novel target gene of parathyroid hormone (PTH)/PTH-related protein in committed osteoblasts. Endocrinology 2009, 150:2244-2253

60. Furuichi K, Gao JL, Horuk R, Wada T, Kaneko S, Murphy PM: Chemokine receptor CCR1 regulates inflammatory cell infiltration after renal ischemia-reperfusion injury. J Immunol 2008, 181:8670-8676

61. Furutani Y, Nomura H, Notake M, Oyamada Y, Fukui T, Yamada M, Larsen CG, Oppenheim JJ, Matsushima K: Cloning and sequencing of the cDNA for human monocyte chemotactic and activating factor (MCAF). Biochem Biophys Res Commun 1989, 159:249-255
62. Yang G, Rosen DG, Zhang Z, Bast RC Jr, Mills GB, Colacino JA, Mercado-Uribe I, Liu J: The chemokine growth-regulated oncogene 1 (Gro-1) links RAS signaling to the senescence of stromal fibroblasts and ovarian tumorigenesis. Proc Natl Acad Sci USA. 2006, 103: 16472-16477

63. Minn AJ, Gupta GP, Siegel PM, Bos PD, Shu W, Giri DD, Viale A, Olshen AB, Gerald WL, Massague J: Genes that mediate breast cancer metastasis to lung. Nature 2005, 436:518-524

64. Kuroda T, Kitadai Y, Tanaka S, Yang X, Mukaida N, Yoshihara M, Chayama K: Monocyte chemoattractant protein-1 transfection induces angiogenesis and tumorigenesis of gastric carcinoma in nude mice via macrophage recruitment. Clin Cancer Res 2005, 11:76297636

65. Avnet S, Longhi A, Salerno M, Halleen JM, Perut F, Granchi D, Ferrar $\mathrm{S}$, Bertoni F, Giunti A, Baldini N: Increased osteoclast activity is associated with aggressiveness of osteosarcoma. Int J Oncol 2008, 33:1231-1238

66. Guan H, Zhou Z, Cao Y, Duan X, Kleinerman ES: VEGF165 promotes the osteolytic bone destruction of Ewing's sarcoma tumors by upregulating RANKL. Oncol Res 2009, 18:117-125

67. Axmann R, Bohm C, Kronke G, Zwerina J, Smolen J, Schett G: Inhibition of interleukin-6 receptor directly blocks osteoclast formation in vitro and in vivo. Arthritis Rheum 2009, 60:2747-2756

68. Barille-Nion S, Bataille R: New insights in myeloma-induced osteolysis. Leuk Lymphoma 2003, 44:1463-1467

69. Kim MS, Day CJ, Selinger Cl, Magno CL, Stephens SR, Morrison NA MCP-1-induced human osteoclast-like cells are tartrate-resistant acid phosphatase. NFATc1, and calcitonin receptor-positive but require receptor activator of NFkappaB ligand for bone resorption. J Bio Chem 2006, 281:1274-1285

70. Kleer CG, Bloushtain-Qimron N, Chen YH, Carrasco D, Hu M, Yao J, Kraeft SK, Collins LC, Sabel MS, Argani P, Gelman R, Schnitt SJ, Krop IE, Polyak K: Epithelial and stromal cathepsin K and CXCL14 expression in breast tumor progression. Clin Cancer Res 2008, 14:53575367

71. Rose AA, Pepin F, Russo C, Abou Khalil JE, Hallett M, Siegel PM: Osteoactivin promotes breast cancer metastasis to bone. Mol Cancer Res 2007, 5:1001-1014

72. El-Tanani MK: Role of osteopontin in cellular signaling and metastatic phenotype. Front Biosci 2008, 13:4276-4284

73. Huang $H$, Zhang XF, Zhou HJ, Xue YH, Dong QZ, Ye QH, Qin LX: Expression and prognostic significance of osteopontin and caspase-3 in hepatocellular carcinoma patients after curative resection. Cancer Sci 2010, 101:1314-1319 